\title{
Effect of Some Aluminum Salts - Amine Ionic Liquids on Several Serum Human Parameters and Bacterial Growth of Klebsiella pneumoniae and Staphylococcus aureus
}

\author{
Bassam B. Hasan ${ }^{1}$, Hadi M. A. Abood ${ }^{1}$ and Nadira S. Mohamed ${ }^{2}$ \\ ${ }^{1}$ Department of Chemistry, College of Science, Al-Nahrain University, Baghdad-Iraq. \\ ${ }^{2}$ Forensic DNA Research and Training Center, Al-Nahrain University, Baghdad-Iraq. \\ Corresponding Author: bassam78bh@yahoo.com.
}

\begin{abstract}
The advantages of pharmaceutics and biological activity of some ionic liquids (ILs) on human serum (HS) and bacterial growth were studied. The effect of aluminum nitrate-acetamide (AN-Ac) and aluminum ammonium sulfate-urea (ammonium alum-urea) ionic liquids were studied on two types of bacterial species gram negative (K.pneumoniae) and gram positive (Staph.aureus). The results showed that the key factors of inhibition are the type, structures, kind of anion and cation of ILs, water miscibility and concentration of ILs and the type of microorganism in both solid and liquid media. Inhibition of bacteria growth was observed to be decreased with decreasing the quantities of (AN-Ac) and (ammonium alum-urea) ILs. The inhibition zone (The Kirby-Bauer Disk Diffusion Test), beside the optical density were measured at $600 \mathrm{~nm}$ for bacterial broth incubated at $37^{\circ} \mathrm{C}$ for $24 \mathrm{hrs}$ with different concentrations of ionic liquids of $(2,5,10,20) \%(\mathrm{v} / \mathrm{v})$. Subsequently, the results of optical densities were calculated as colony forming units (CFUs). The concentration of ILs was calculated practically until it reached the optimal concentration of $2 \%(\mathrm{v} / \mathrm{v})$. This concentration caused no variation on serum parameters likes sugar, lipid profile, protein, liver functions, kidney functions, and electrolytes, obtained by using Automatic biochemistry analyzers technique.
\end{abstract}

[DOI: $\underline{10.22401 / J U N S .21 .1 .03]}$

Keywords: Ionic Liquids, Inhibition, bactericidal, human serum.

\section{Introduction}

Ionic liquids are salts consisting of ions, which exist in the liquid state at ambient temperatures [1]. They show reasonably high ionic conductivities. The ability of ionic liquids to enter into many biological and chemical fields came from their rare properties such as non-flammable, sparsely volatile, high conductivity, good dissolution power towards many substrates and high thermal and chemical stability [2]. For these unique properties, ionic liquids have been extensively known

as solvents, cosolvents or co-catalysts in different biological applications, including biotechnology [3], biomass conversion [4], biotransformation [5], biocatalytic [6], studies on human serum albumin [7-8] and many other fields. Besides remarkable properties and use as solvents, the tunable nature of ILs has encouraged the improvement of novel profitable subjects. The number of research articles involving ILs are growing significantly. It is intriguing to note that the focus of numerous IL studies now develops toward life sciences and medicine, and suggested that in the following years biomedical applications of ILs would probably become one of the main research developments [9]. Moreover, in a close term point of view, competent drugs based on ILs may be considered for agreement by FDA [10]. Interest in the biological efficacy of ILs and their application in pharmaceutics and medicine are newly developed, very important regions. However, ILs have developed as a new kind of non-aqueous polar solvents for biocatalysis, because they can alleviate and stimulate enzymes [11]. Ionic liquids to be considered as so called "green solvents" should be nontoxic or have only little toxicity to living organisms and the environment [12]. Many new ionic liquids are developed [13-14] these ionic liquids needs to be evaluated for their biological effect to determined their extent on human patient prepared or used for different applications. In the present work the ionic liquids of the type (AN-Ac) and 
(ammonium alum-urea) are prepared and reported to have some useful application. However their biological properties needs to be studied to establish their effect on human body.

\section{Materials and Methods}

All chemicals were used without any further purification aluminum nitrate, ammonium aluminum sulfate dodecahydrate (BDH England) and acetamide (Fluka Germany). The K.peneumonice and Staph.aureus bacteria were diagnosed and isolated in microbiology laboratories of $\mathrm{Al}$ Karama hospital, Baghdad, which grown in nutrient broth (NB) (M002 HIMEDIA, India). The solid media for antimicrobial activity testing Mueller Hinton Agar (MHA) (M173 HIMEDIA, India) and for colony forming units (CFUs) nutrient agar (NA) (M001 HIMEDIA, India) were used. Optical density was

measured at $600 \mathrm{~nm}$ using SHIMADZU UV spectrophotometer (UV-1800 JAPAN). Automatic biochemistry analyzers (ARCHITECT c4000 Abbott core laboratory made in USA) was used for serum test.

\section{Ionic liquids preparation}

A procedure previously reported for preparation of (1:3) mole ratio of AN-Ac [13] and (1:5) mole ratio of ammonium alum-urea [14] ionic liquids was adopted in this work. A proper amount of each aluminum salt was weighted out mixed with urea and heated gradually up to $80^{\circ} \mathrm{C}$ and left at this temperature for $3 \mathrm{hrs}$. When cooled down to room temperature they become a clear colorless liquid.

\section{Cultivation conditions}

\section{A. Liquid cultures}

Bacteria was prepared by inoculation a $25 \mu 1$ of standard bacteria in sterile tube contained $5 \mathrm{ml} \mathrm{NB}$. After incubation at $37^{\circ} \mathrm{C}$ for $24 \mathrm{hrs}$ the suspension of bacteria was formed, then $100 \mu \mathrm{l}$ was taken from the culture and transferred to $5 \mathrm{ml}$ of fresh media in a new sterile tubes containing series concentrations of (AN-Ac) and (ammonium alum-urea) ionic liquids of $(2,5,10$ and 20$) \%(\mathrm{v} / \mathrm{v})$ which were incubated at $37^{\circ} \mathrm{C}$ for $24 \mathrm{hrs}$. Subsequently all bacterial growth were estimated from optical density measurements.

\section{B. Solid cultures}

Culture media of NA plates with $2 \%$ and $5 \%$ ILs concentration were used for colony counting to determine the number of viable cells. Plates of $60 \mathrm{~mm}$ in diameter with final volume of $15 \mathrm{ml}$ of agar were poured and bacterial culture were spread using sterile glass spreader rod. Each number of colonies in solid plate were counted after $24 \mathrm{hrs}$ incubation at $37^{\circ} \mathrm{C}$. Colonies of bacteria that were formed on the solid culture plates, were converted into the colony forming units (CFUs). On the other hand, culture media MHA was used for antimicrobial activity (The Kirby-Bauer Disk Diffusion Test) containing (K.peneumonice and St.aureus Severally) on agar surface using sterile cotton swab and then holes were made in the agar plate filled up with $50 \mu \mathrm{L}$ of (ANAc) and (ammonium alum-urea) ILs to individually the anti-bacterial activity.

\section{Biochemical Testes}

Elaboration experiments were performed initially for ILs without dilution, which showed an extremely effective results toward serum leading to an agglomerate. Therefore ILs was diluted with deionized water till reaching an optimal concentration of $2 \%$ (v/v) which had no effect on blood serum parameters. A statistical analysis of serum parameters was performed on 50 patients at Al-Yarmouk Teaching Hospital in Baghdad to elucidate the appropriate ILs concentration.

\section{Results and Discussion}

Through antimicrobial activity test (The Kirby-Bauer Disk Diffusion Test) showed that both (AN-Ac) and (ammonium alum-urea) ILs decreased the activity of K.peneumonice and Staph.aureus bacteria growth indicted by measuring the inhibition zone diameter as shown below in Table (1), and Fig.(1):

Table (1)

Inhibition zone diameters of $A N-A c$ and ammonium alum-urea ILs on K.peneumoniae and Staph.aureus bacteria. 


\begin{tabular}{|c||c||c|}
\hline AN-Ac & $25 \mathrm{~mm}$ & $27 \mathrm{~mm}$ \\
\hline \hline $\begin{array}{c}\text { Ammonium } \\
\text { alum-urea }\end{array}$ & $17 \mathrm{~mm}$ & $22 \mathrm{~mm}$ \\
\hline
\end{tabular}

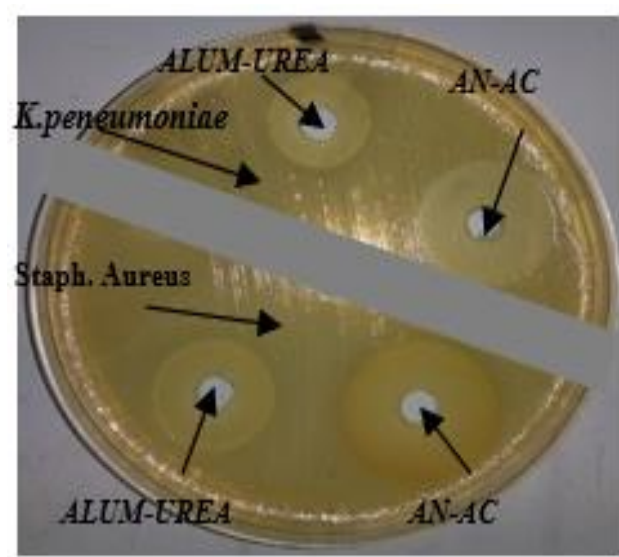

Fig.(1): The effect of $A N-A C$ and $A L U M-$ UREA ILs on K.peneumoniae and Staph.aureus bacteria by Kirby-Bauer Disk Diffusion Test.

Table (1) represents the inhibtion zoon diameter of both (AN-Ac) and (ammonium alum-urea) ILs on K.peneumoniae and Staph.aureus bacteria. It can be noted that the inhibition zone of AN-Ac IL is more than ammonium alum-urea IL in both types of bacteria and that indicated an ability of AN-Ac IL to inhibit and kill bacteria more than ammonium alum-urea IL. The rate of diffusion is governed by the physical and chemical properties of ILs. Their relative hydrophobicity, aqueous solubility, and molecular weight dictate the extent of diffusion through the agar [15-17]. Therefor this technique is considered to give a qualitative perception of the effectiveness of ILs on the growth of bacteria.

The optical density (OD) was measured for the broth ager of K.peneumonice and St.aureus bacteria culture, with $2 \%, 5 \%, 10 \%$ and $20 \%$ (v/v) concentration of ILs. The OD value without incubation was subtracted from the results which are shown in Table (2) and Fig.(2.A and B).
Table (2)

The optical density (OD) value for K.peneumonice and S.aureus bacteria culture with deferent concentration of ILs (The OD value without incubation was subtracted from the result).

\begin{tabular}{|c||c||c||c|}
\hline $\begin{array}{c}\text { The type of } \\
\text { bacteria }\end{array}$ & $\begin{array}{c}\text { Concentration } \\
\boldsymbol{v} / \boldsymbol{v}\end{array}$ & $\begin{array}{c}\boldsymbol{A N}- \\
\boldsymbol{A c}\end{array}$ & $\begin{array}{c}\text { ammonium } \\
\text { alum-urea }\end{array}$ \\
\hline \hline \multirow{3}{*}{ K.peneumonice } & $2 \%$ & 0.080 & 0.097 \\
\cline { 2 - 4 } & $5 \%$ & 0.025 & 0.030 \\
\cline { 2 - 4 } & $10 \%$ & 0.009 & 0.012 \\
\hline \hline \multirow{3}{*}{ Staph.aureus } & $20 \%$ & 0.000 & 0.005 \\
\cline { 2 - 4 } & $2 \%$ & 0.039 & 0.057 \\
\cline { 2 - 4 } & $5 \%$ & 0.014 & 0.027 \\
\cline { 2 - 4 } & $10 \%$ & 0.002 & 0.006 \\
\hline
\end{tabular}

Notes:

- K.peneumonice: 0.706 (control solution $)$ Blank $=($ Broth $+100 \mu \mathrm{l}$ K.peneumoniae without incubation:0.042)

- Staph.aureus: 0.470 (control solution)Blank $=($ Broth $+100 \mu \mathrm{l}$ Staph.aureus without incubation:0.025)
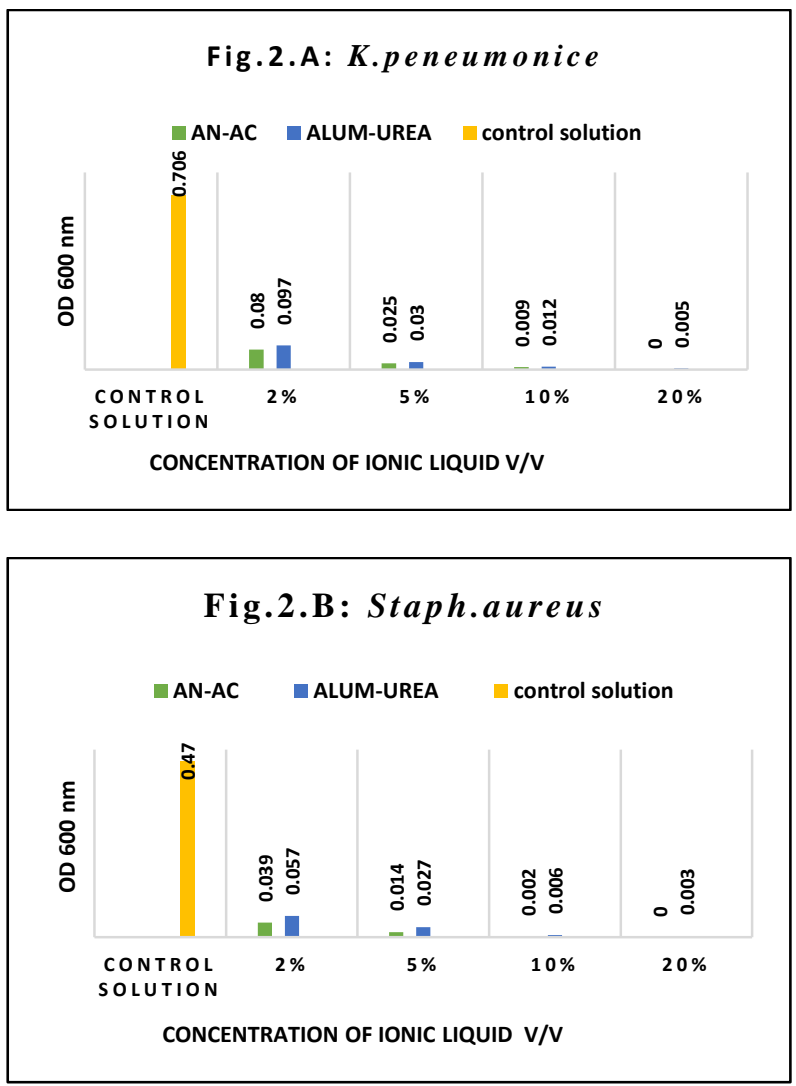
Fig.(2): The optical density value for $A$. K.peneumonice and B. S.aureus bacteria with deferent concentration of ILs.

To preform Colony forming units a $0.1 \mathrm{ml}$, each tube was serial diluted and spread on solid media. The data of this test shown in Table (3) and Figs. (3.A, B and 4).

Table (3)

The effect of ILs on bacterial cells count $(\mathrm{CFU}) / \mathrm{ml}$.

\begin{tabular}{|c|c|c|c|}
\hline $\begin{array}{l}\text { Ttype of } \\
\text { bacteria }\end{array}$ & $\begin{array}{c}\text { Concentratio } \\
n v / v\end{array}$ & $\begin{array}{c}A N-A c \\
(C F U s) \\
/ m l \\
\end{array}$ & $\begin{array}{l}\text { ammonium } \\
\text { alum-urea } \\
(\mathrm{CFUs}) / \mathrm{ml} \\
\end{array}$ \\
\hline \multirow{2}{*}{ K.peneumoniae } & $2 \%$ & $\underset{6}{116 x 10}$ & $235 \times 10^{6}$ \\
\hline & $5 \%$ & $33 \times 10^{4}$ & $58 \times 10^{4}$ \\
\hline \multirow{2}{*}{ Staph.aureus } & $2 \%$ & $11 \times 10^{5}$ & $63 \times 10^{6}$ \\
\hline & $5 \%$ & $16 \times 10^{2}$ & 1 r $0 \times 10^{4}$ \\
\hline
\end{tabular}
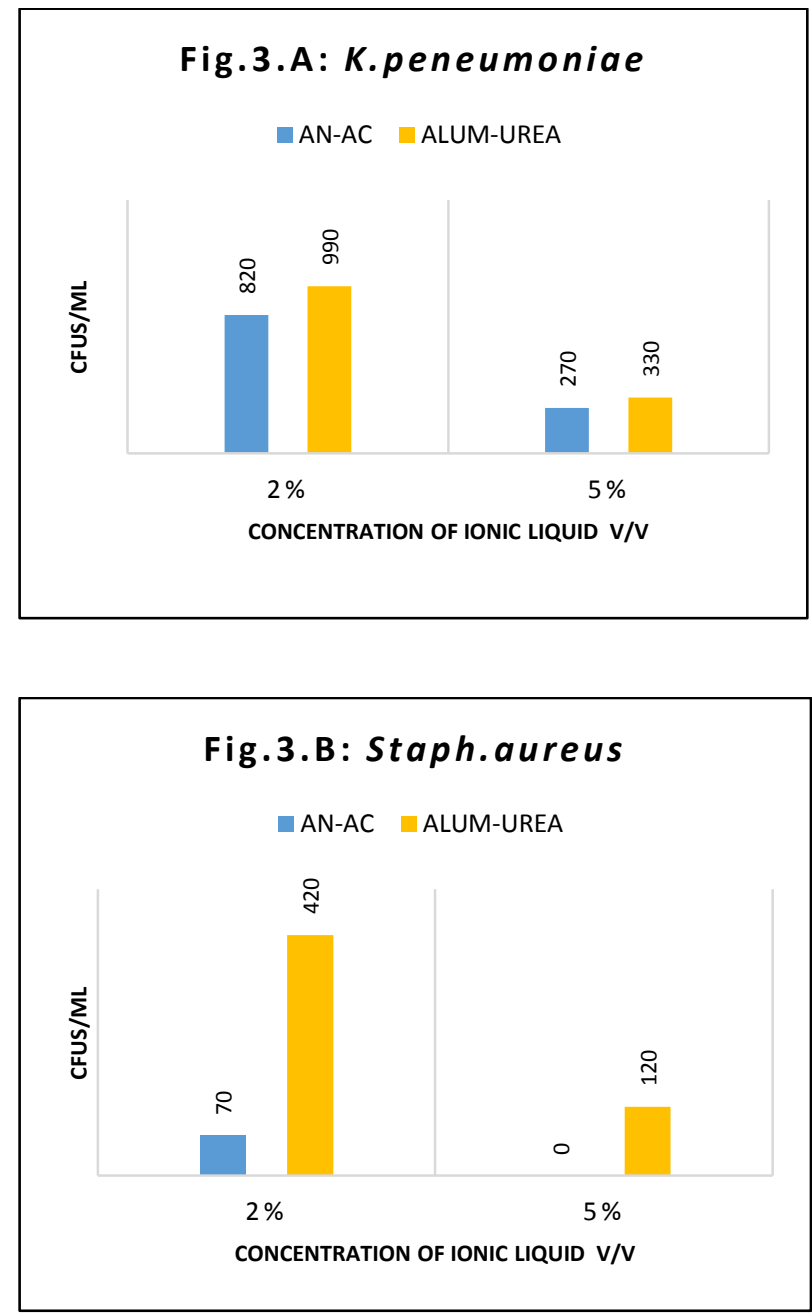

Fig.(3): The effect of (AN-Ac) and (ammonium alum-urea) ILs on A. K.peneumoniae and $B$. Staph.aureus bacterial viability $(\mathrm{CFUs}) / \mathrm{ml}$. 
A.

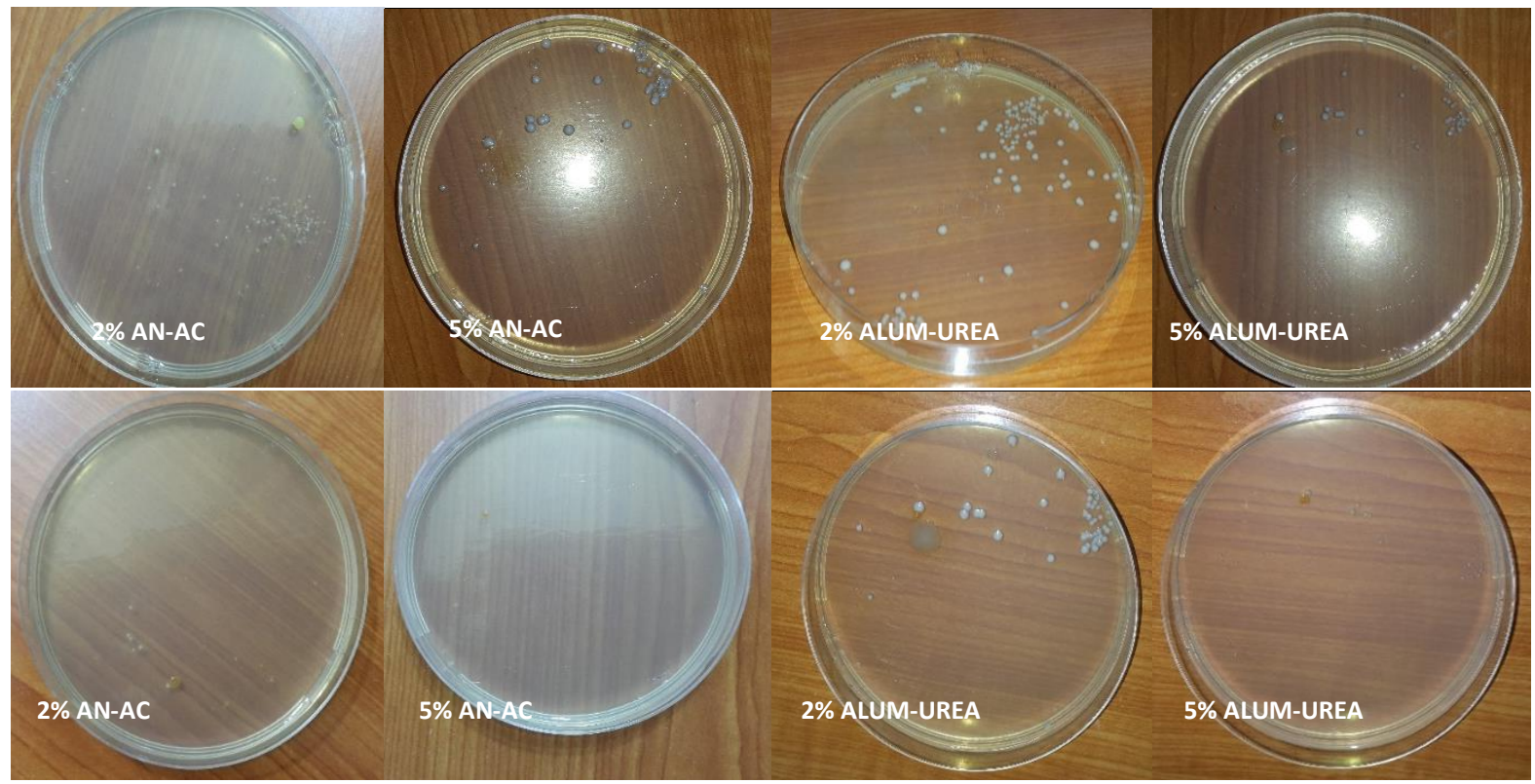

Fig.(4): Colony forming counting on the agar media for A. K.peneumoniae and

\section{B. St.aureus in $2 \%, 5 \%$ of IL treatment.}

The OD and CFUs tests, Table (2) and Table (3) respectively indicated that at increase in (AN-Ac) and (ammonium alumurea) ILs concentrations it decreases the K.peneumonice and St.aureus bacterial growth rate, as the $2 \%$ ILs concentration is considered to be the minimum inhibitory concentration (MIC) and $10 \%$ is the minimum of bactericidal concentration (MBC). It is worth mentioning that ionic liquids of present research have a toxicity effect against gram (positive and negative) bacteria with different cation and anion species. These results correspond with an effect reported by Jungnickel, et al [18] and You YU, and Yi Nie [19], researches used deferent ionic liquids on various bacteria.

The effect of ionic liquids on human serum was determined by examining changes in clinical biochemical testes and selecting the optimal concentration. Both ionic liquids (ANAc) and (ammonium alum-urea) when added without dilution, an aggregation of the serum was observed Fig.(5), because ionic liquids can probably alter the structure, dynamics, function, and stability of proteins and fats [8]. The ionic liquids were then diluted until reaching to the optimal concentration without affecting the serum parameters. $3 \mu 1$ of $2 \% \mathrm{v} / \mathrm{v}$ ideal concentration of ionic liquids was added to $300 \mu \mathrm{l}$ serum, when dilution showed no effect on serum parameters. This concentration was applied on 50 patients serum tested for number of clinical biochemistry tests such as (sugar, lipid profile, protein, liver functions, kidney functions, and electrolytes) that showed in Figures (6/A, B, C, D, E, F, G, H, I, J, K, L, $\mathrm{M}, \mathrm{N}, \mathrm{O}$ and $\mathrm{P}$.). The result of patient (1) was taken as an example as shown in Table (4).

\section{Table (4)}

\section{Clinical biochemical testes for serum human} with $2 \%$ of ionic liquid for patient 1.

\begin{tabular}{|c|c|c|c|c|c|}
\hline \multicolumn{6}{|c|}{$\begin{array}{c}\text { Patient ID: } 1 \text { / Gender: Female / Age: } 42 \text { / Draw Time: Morning/ } \\
\text { Type of test: Random }\end{array}$} \\
\hline \multirow[b]{2}{*}{ Assay } & \multicolumn{3}{|c|}{ Result } & \multirow[b]{2}{*}{ Range } & \multirow[b]{2}{*}{ Units } \\
\hline & CONTROL & $\begin{array}{l}\text { ALUM- } \\
\text { UREA }\end{array}$ & $\begin{array}{l}A N- \\
A C\end{array}$ & & \\
\hline GluC & 102 & 98 & 98 & $65-110$ & $\mathrm{Mg} / \mathrm{dl}$ \\
\hline Urea & 28 & 43 & 27 & $20-50$ & $\mathrm{Mg} / \mathrm{dl}$ \\
\hline $\mathrm{CeaC}$ & 0.65 & 0.64 & 0.66 & $0.57-1.25$ & $\mathrm{Mg} / \mathrm{dl}$ \\
\hline AlbG & 4.4 & 4.4 & 4.4 & $3.5-5.0$ & $\mathrm{~g} / \mathrm{dl}$ \\
\hline TP & 7.7 & 7.6 & 7.6 & $6.4-8.3$ & $\mathrm{~g} / \mathrm{dl}$ \\
\hline ALT & 6 & 7 & 8 & $0-55$ & $\mathrm{U} / \mathrm{L}$ \\
\hline AST & 17 & 16 & 16 & $5-34$ & $\mathrm{U} / \mathrm{L}$ \\
\hline AlkP & 117 & 115 & 114 & $40-150$ & $\mathrm{U} / \mathrm{L}$ \\
\hline BiliT & 0.8 & 0.7 & 0.7 & $0.2-1.2$ & $\mathrm{Mg} / \mathrm{dl}$ \\
\hline
\end{tabular}




\begin{tabular}{||c||c||c||c||c||c||}
\hline BilD & 0.4 & 0.3 & 0.3 & $0.0-0.5$ & $\mathrm{Mg} / \mathrm{dl}$ \\
\hline \hline Chol & 176 & 169 & 171 & $0-199$ & $\mathrm{Mg} / \mathrm{dl}$ \\
\hline \hline Trig & 81 & 78 & 77 & $0-149$ & $\mathrm{Mg} / \mathrm{dl}$ \\
\hline \hline CaC & 9.5 & 9.6 & 9.8 & $8.4-10.2$ & $\mathrm{Mg} / \mathrm{dl}$ \\
\hline \hline UA & 2.92 & 2.94 & 2.93 & $3.50-7.20$ & $\mathrm{Mg} / \mathrm{dl}$ \\
\hline \hline Cl-C & 105 & 103 & 103 & $98-107$ & $\mathrm{mmol} / \mathrm{L}$ \\
\hline \hline K-C & 4.2 & 4.2 & 4.2 & $3.5-5.1$ & $\mathrm{mmol} / \mathrm{L}$ \\
\hline \hline Na-C & 140 & 138 & 138 & $136-145$ & $\mathrm{mmol} / \mathrm{L}$ \\
\hline
\end{tabular}

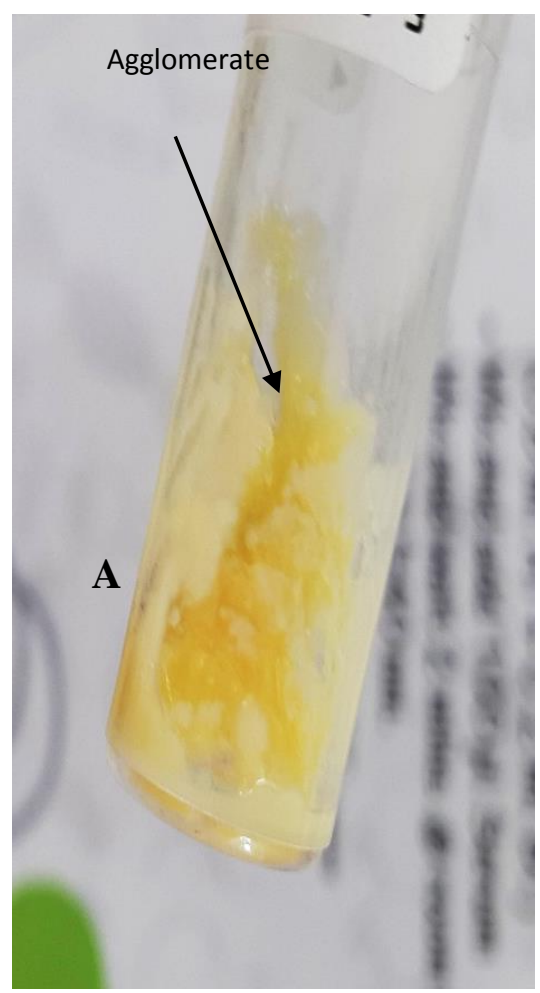

Fig.(5): The effect of original ionic liquids on serum. A: ammonium alum-urea, $B: A N-A c$.
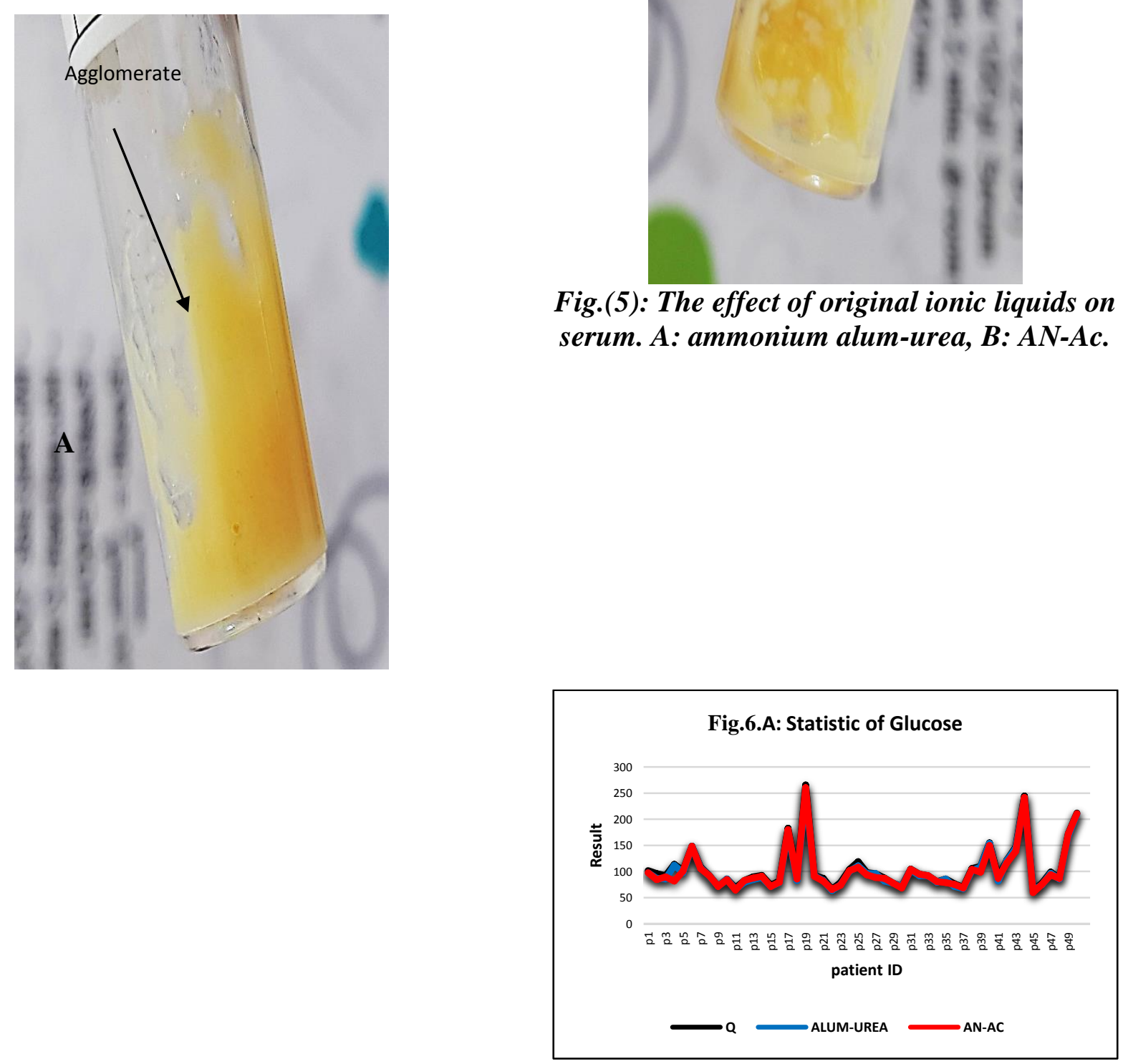

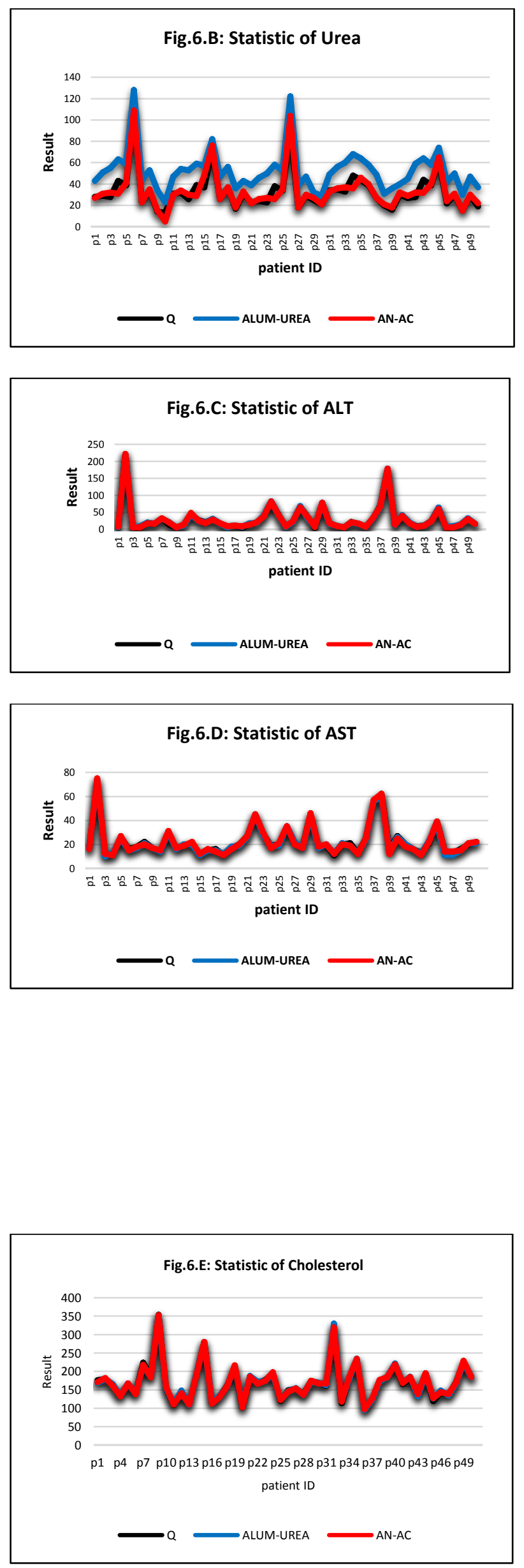
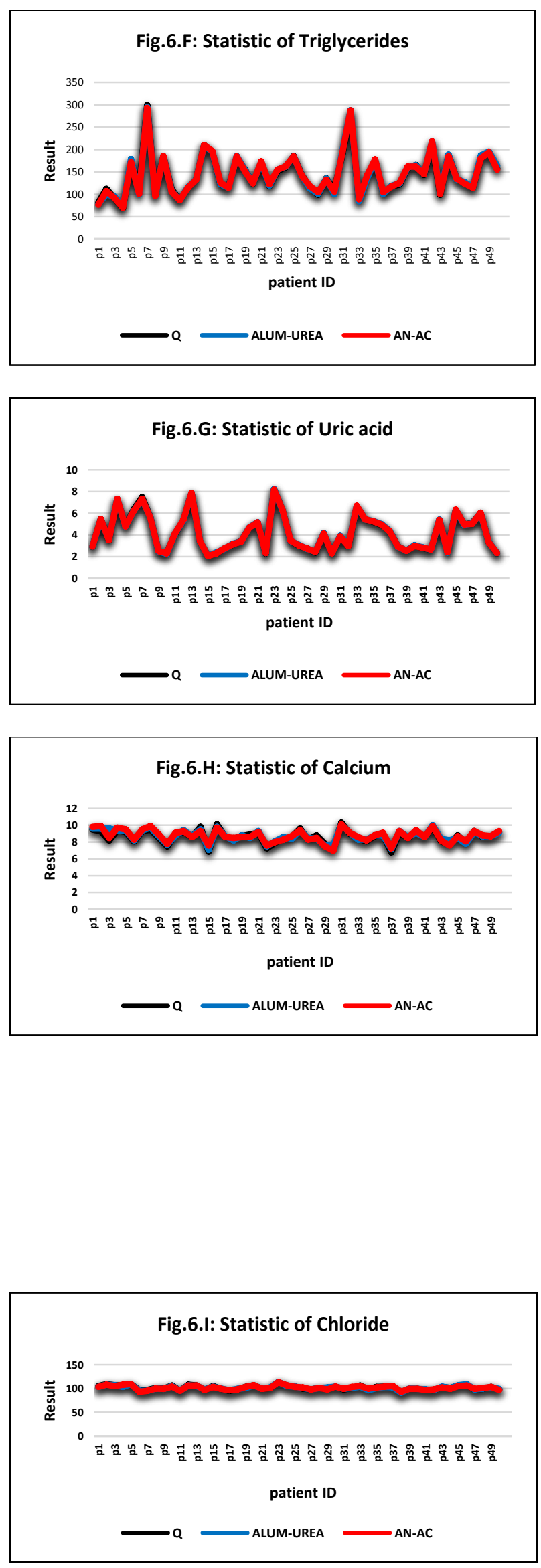

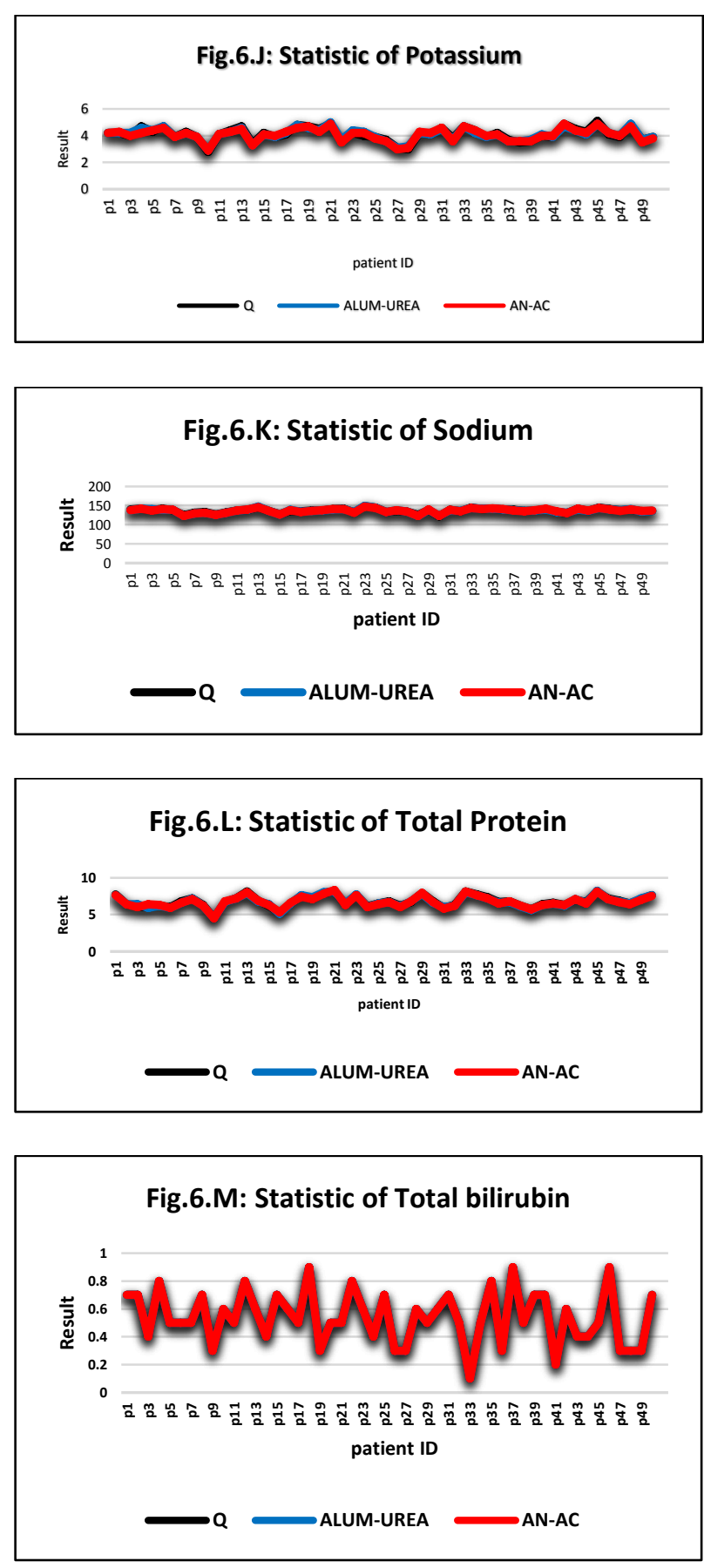

Fig.6.N: Statistic of Alkaline Phosphatase
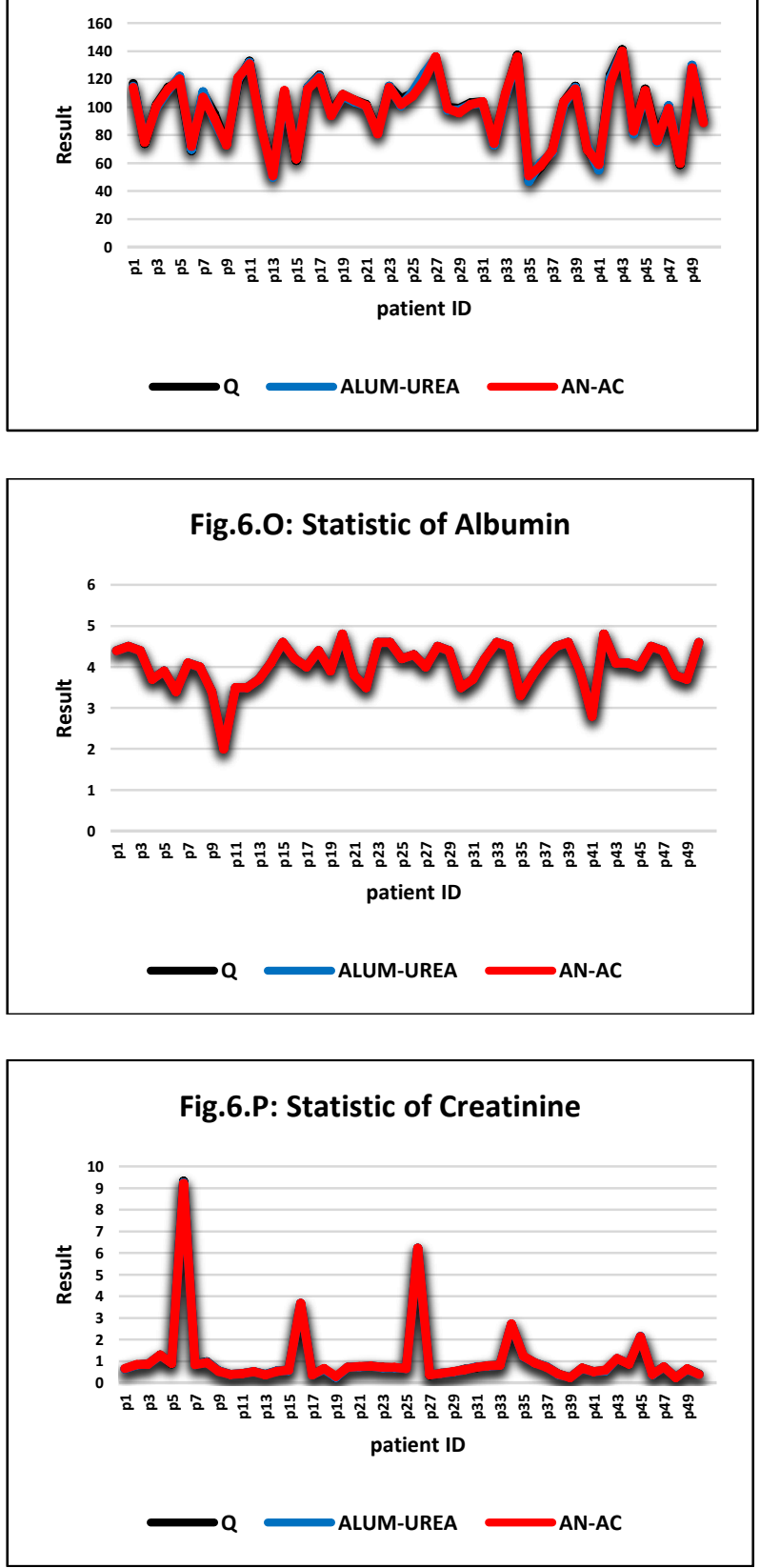

Fig. (6): A statistic was performed for each serum parameters with and without ionic liquids, as shown in the following graphs. Where

Aluminum nitrate - acetamide IL,

Aluminum ammonium sulfate-urea $I L$, Q: patient's serum without any additives.

A: Statistic of Glucose, B: Statistic of Urea, $C$ : Statistic of ALT, D: Statistic of AST, E: Statistic of Cholesterol, F: Statistic of Triglycerides, G: Statistic of Uric acid, H: Statistic of Calcium, I: Statistic of Chloride, J: Statistic of Potassium, K: Statistic of Sodium, L: Statistic of Total Protein, M: Statistic of Total bilirubin, N: Statistic of Alkaline Phosphatase, O: Statistic of Albumin, P: Statistic of Creatinine. 
This study indicated that all serum parameters were stable in $2 \% \quad(\mathrm{v} / \mathrm{v})$ concentration of ILs, except serum urea test which showed an increase value over the initial patient urea test which might be due to the presence of amides groups in ILs. This increase was found in ammonium alum-urea IL value than in AN-Ac IL because it contains two amide groups compared with the one amide group in AN-Ac IL. In spite of the relative increase in the level of serum urea, but it is still within the normal level $(20-50 \mathrm{mg} / \mathrm{dl})$ of urea human body.

\section{Inhibition Mechanism}

The toxic influence of ILs may be related to a common cellular structure or process. It was reported that the toxicity mechanism of ILs was related to an interaction of IL with the cell wall and membrane, leading to a membrane disorder [18]. It was also reported that ILs containing cation-anion pairs has similar behavior of surfactants, pesticides and antibiotics that attack lipid structure, and stimulate polar narcosis, and may cause membrane-bound protein disorder [19].

\section{Conclusions}

The AN-Ac and ammonium alum-urea ILs can be used as biological active liquid, as they showed inhibition activities of MIC (for $2 \% \mathrm{v} / \mathrm{v}$ ILs) and MBC (for $10 \% \mathrm{v} / \mathrm{v}$ ILs) on the metabolism of K.peneumonice and S.aureus which may follow the inhibition mechanism on the bacterial growth of antibiotic drags. On the other hand the optimal concentration $(2 \% \mathrm{v} / \mathrm{v})$ of all studied ILs did not show an effect on serum parameters. Therefore this concentration can be used as antibiotic or in different biochemical experiments.

\section{Reference}

[1] Zhao D., Wu M., Kou Y., Min E., Catal. Today 74, 157, 2002.

[2] Wasserscheid, P., and Welton, T., Ionic Liquids in Synthesis, 2nd ed.; Wiley-VCH: Weinheim, 2007.

[3] Dominguez de Marıá P., Ed.; Ionic Liquids in Biotransformations and Organocatalysis: Solvents and Beyond; Wiley \& Sons, Inc.: Hoboken, NJ, 2012.
[4] Pinkert A., Marsh, K. N., Pang S., Staiger M. P. Ionic Liquids and Their Interaction with Cellulose. Chem. Rev, 109, 6712-6728, 2009.

[5] Domínguez de María, P. "Nonsolvent" Applications of Ionic Liquids in Biotransformations and Organocatalysis. Angew. Chem., Int. Ed., 47, 6960-6968, 2008.

[6] Van Rantwijk F., Sheldon R. A. Biocatalysis in Ionic Liquids. Chem. Rev, 107, 2757-2785, 2007.

[7] Vance W. Jaeger., Jim Pfaendtner. Destabilization of Human Serum Albumin by Ionic Liquids Studied Using Enhanced Molecular Dynamics Simulations. J. Phys. Chem. B, 120 (47), 12079-12087, 2016.

[8] Yasar Akdogan., Matthias J. N. Junk; Dariush Hinderberger. Effect of Ionic Liquids on the Solution Structure of Human Serum Albumin. Biomacromolecules, 1072-1079, 2011.

[9] Heckenbach M. E., Romero F. N., Green M. D., Halden, R. U. Meta-Analysis of Ionic Liquid Literature and Toxicology. Chemosphere, 150, 266-274, 2016.

[10] Shamshina J. L., Kelley S. P., Gurau G., Rogers, R. D. Develop Ionic Liquid Drugs. Nature, 528, 188-189, 2015.

[11] Yang Z., Pan W., Ionic liquids: Green solvents for nonaqueous biocatalysis, Elsevier Enzyme and microbial technology, 37:19-28, 2005.

[12] Kaftzik N., Wasserscheid P., Kragl U., Use of Ionic Liquids to Increase the Yield and Enzyme Stability in the $\beta$-Galactosidase Catalysed Synthesis of N-Acetyllactosamine, Organic Process Research \& Development, 6:553-557, 2002

[13] Abood H. M. A., "New ionic liquid made from hydrated aluminum sulfate with amide", Patent, Central Organization for Standardization and Quality, Property division, Iraq, Application, 336, 3915, 2011.

[14] Hasan N. M., Abood H. M. A. And M. F. Alias. Investigation of the New Room Temperature Ionic Liquid of $\mathrm{Al}\left(\mathrm{NO}_{3}\right)_{3} .9 \mathrm{H}_{2} \mathrm{O}$ with Urea $\mathrm{CO}\left(\mathrm{NH}_{2}\right)_{2}$. bsj .10.2112, 2016.

[15] Docherty K. M. and Kulpa C.F. "Toxicity and Antim-icrobial Activity of Imidazolium 
and pyridinium ionic Liquids," Green Chemistry, 185-189, 2005.

[16] Bernot R.J., Kennedy E.E and G. A. Lamberti, "Effects of Ionic Liquids on the Survival, Movement, and Feeding Behavior of the Freshwater Snail, Physa Acuta," Environmental Toxicology and chemistry, 1759-1765, 2005.

[17] Maheshwari, R., Indian Journal of Microbiolgy, 181-183, 2007.

[18] Jungnickel, C., Luczak, J., Ranke, J., Fernandez, J.; Muller, A.; Thoming, J.; Colloids and Surfaces A: Physicochem. Eng. Aspects, (316), 278-284, 2008.

[19] You YU, and Yi Nie., Toxicity and Antimicrobial Activities of Ionic Liquids with Halogen Anion. Journal of Environmental Protection, 2, 298-303, 2011/ 